\title{
LITERATURA INFANTIL EM CENA: O TEATRO COMO ESTRATÉGIA PEDAGÓGICA
}

\author{
Priscila Peixinho FIORINDO \\ (Universidade do Estado da Bahia) \\ priscilafiorindo@hotmail.com \\ Ney WENDELL \\ (Université du Québec à Montréal) \\ ney.arte@hotmail.com
}

Resumo: $O$ artigo apresenta o gênero teatral enquanto estratégia pedagógica para o trabalho com literatura infantil nas aulas do Ensino Fundamental I. Inicialmente ressaltamos a importância da diversificação de gêneros para desenvolver aulas mais lúdicas e criativas. Logo após, mostramos os mecanismos pedagógicos e didáticos do teatro na escola e sua interface direta com a literatura. Nesta perspectiva, apresentamos um relato de experiência, no qual as alunas do Programa do Mestrado Profissional em Letras/PROFLETRAS, da Universidade do Estado da Bahia/UNEB, Campus $\mathrm{V}$, a fim de vivenciar o referido gênero, criaram uma história a partir da seguinte orientação: criar um enredo original de uma peça teatral. Com base na produção encenada "De geração para geração..." observamos a criatividade, desde a elaboração do cenário até a construção das falas de cada uma e, ao mesmo tempo, verificamos o potencial crítico que essas alunas/professoras podem desenvolver, primeiramente, em si próprias, para depois trabalharem com seus educandos. Ao final, constatamos a relevância do trabalho com o teatro na educação infantil, devido ao estímulo da prática da criatividade, com a expressão oral e corporal, valorizando a riqueza do imaginário cênico trazido pela literatura, que conduz o educando a olhar a cena na vida, com observação dos detalhes nas relações humanas.

Palavras-chave: Literatura. Teatro. Educação Infantil. Estratégia pedagógica.

\section{CHILDREN'S LITERATURE ON THE STAGE: THEATRE AS A PEDAGOGICAL STRATEGY}

\begin{abstract}
The article presents the theatrical genre as a pedagogical tool to be used with children's literature in elementary school classes. First, we address the importance of diversifying genres to develop more ludic and creative classes. Then, we demonstrate the pedagogical and didactic mechanisms of theatre at school, as well as its direct interface with literature. On the basis of the theatrical genre, we report an experience in which the students of the Professional Master's course in Literature (PROFLETRAS of the State University of Bahia/UNEB Campus V) created a story based on the following directions: create the original plot of a play". Based on their staged production of "From generation to generation..." we observe the burst of creativity generated by the elaboration of the plot to the construction of the dialogues. At the same time, we verify the critical
\end{abstract}

Pensares em Revista, São Gonçalo-RJ, n. 5, pág. 113 - , jul./dez. 2014

DOI: http://dx.doi.org/10.12957/pr.2014.14057 
potential that those students/teachers can develop, firstly in themselves, and afterwards to work it up their learners. In the end, we could ascertain the relevance of using theatre in early childhood education. Creativity is highly stimulated through oral and physical expression, valuing the richness of the scenic imagination brought about by literature, which leads the student to look at life by observing the details of human relations.

Keywords: Literature. Theatre. Early childhood education. Pedagogical strategy.

\section{Introdução}

A escola é um ambiente diversificado que solicita habilidades criativas dos professores para que eles mostrem muitas opções lúdicas no seu ato dinâmico de ensinar. O uso de elementos criativos e lúdicos no decorrer das atividades em classe contribui para que o aluno aprenda aquilo que está sendo trabalhado, através da dinamicidade do brincar e do prazer de criar com os conteúdos. Estas práticas diferenciadas são escolhidas a partir de uma relação direta entre os perfis dos educandos e os conhecimentos abordados nas disciplinas.

Nesta perspectiva, é relevante desenvolver a teoria de cada disciplina numa prática que estimule o potencial criador do aprendiz. Seja na área de humanas, exatas, ciências e/ou biológicas, é fundamental usar metodologias diversas e criativas para colocar o educando dentro da experiência dinâmica do processo ensino-aprendizagem, pois é a partir desta pluralidade de experiências vividas por ele que o conhecimento se concretiza e se internaliza.

$\mathrm{Na}$ área de humanas, especificamente, durante as aulas de Língua Portuguesa, no Ensino Fundamental I, a literatura deve ser ofertada de forma dinâmica, conforme as exigências dos Parâmetros Curriculares Nacionais/PCNs (BRASIL,1998). São estes documentos oficiais que ressaltam a necessidade de se trabalhar com os diversos gêneros, escritos e orais, na aquisição do conhecimento, a fim de criar e recriar a partir de diferentes repertórios linguísticos.

De acordo com Alcoforado (2008), o fenômeno literário, como uma criação estética da linguagem, não significa que essa criação só possa ser efetivada através da modalidade escrita. Levando em conta que a realidade de uma época, com os costumes, tradições, histórias contadas e cantigas folclóricas, é 
representada na e pela literatura, então não podemos desconsiderar a literatura oral, característica histórico-social de um povo.

A título de ilustração, dentro de nosso contexto, observamos algumas cantigas de roda que nos foi apresentada logo na primeira infância - "o cravo brigou com a rosa", "escravos de Jó", entre outras, que fazem parte do acervo histórico cultural brasileiro. Toda esta riqueza da cultura oral pode ser inserida em sala de aula, no processo lúdico de aprendizagem que coloca o educando como um recriador da linguagem.

A literatura, conforme Coelho (1966), é a vida transformada em palavras e, para esse processo acontecer, recorremos ao imaginário, fundamental, pois nós vivemos muito mais pelo simbólico do que pela ação concreta.

Para Sarmento e Tufano (2010), a literatura é um espaço em que a linguagem é muito mais trabalhada, a fim de causar efeitos estéticos, por isso há nela maior liberdade em relação às regras gramaticais ou sintáticas, criação de palavras, variação de elementos gráficos, como por exemplo, tamanhos de letras, uso de cores, entre outros recursos. Explorando o sentido conotativo das palavras, o escritor quebra a rotina da linguagem e estimula o leitor a participar do texto, aguçando sua curiosidade intelectual e sua sensibilidade estética. Nesta vertente, o texto literário não tem um sentido pré-determinado, ele é, antes, um campo de possibilidades.

Diante do exposto, o texto literário pode ser apresentado em diversos gêneros, tais como mitos e lendas, contos fantásticos e maravilhosos, mistério e terror, histórias em quadrinhos, diários e memórias, poesia, teatro... Assim, privilegiamos aqui o gênero teatro, enquanto estratégia pedagógica no Ensino Fundamental I. Isso porque o teatro é um gênero que integra a ludicidade e a criatividade, a partir da união entre oralidade e corporeidade, na expressão comunicativa do educando. Além disso, a linguagem teatral dramática possibilita que as palavras e a riqueza dos elementos textuais ganhem vida nos personagens e no conjunto da encenação. Dessa forma, focalizamos neste artigo a teatralidade na sua relação direta com a literatura infantil, mostrando o imaginário da cena como ação concreta, em que o educando aprende vivendo as histórias e os personagens. 


\section{2 - O gênero teatro: uma pedagogia lúdica}

Considerando o teatro como um gênero da literatura, nos apoiamos em Costa (2008, p. 146) que define o referido gênero como:

Texto escrito ou encenado em que os diálogos são os que mais bem imitam as situações reais. Nelas os personagens conversam entre si para dar ao espectador a sensação de estar dentro da cena. Na peça de teatro não existe a figura do narrador, apenas os diálogos e a rubricas, que orientam o leitor ou o diretor sobre a montagem da cena, o figurino usado pelos personagens e a entonação da voz, por exemplo. A maneira como as coisas são ditas permite ao leitor fazer inferências sobre as características de cada personagem e compreender os conflitos da trama.

No aspecto do trabalho com a literatura infantil, o teatro possui quatro funções enquanto gênero literário, descritos a seguir.

1) Recriar a realidade em cena: o teatro é uma arte das relações humanas, como afirma Esslin (1978, p. 24), ao esclarecer que o "drama é a forma mais concreta na qual a arte pode recriar situações de relações humanas [...]". Neste sentido, a cena mostra, através da textualidade impressa nos personagens e na história, a vida por meio das relações interpessoais. A realidade é encenada para mostrar a riqueza concreta ou onírica da vida; e a diversidade de narrativas encenadas pode mostrar, no palco, a relação de um personagem consigo mesmo ou com o outro, afirmando o lugar do indivíduo, com seus conflitos, sonhos e escolhas.

2) Integrar o indivíduo ao mundo imaginário: o palco é um espaço vazio que será preenchido por elementos da cena, criado pelo autor no texto escrito ou improvisado. A magia do teatro está ligada ao mundo imaginário que é construído pelos artistas e pelo público, no ato único e efêmero de uma apresentação. Por isso, o educando se sente estimulado a criar, pois ele utiliza sua imaginação para viver momentos lúdicos no universo cenográfico.

3) Explorar a estética da comunicação verbal: as palavras ganham vida no texto teatral, pois elas estão na fala de um personagem ou na descrição das ações, construindo uma realidade estética e, ao mesmo tempo, ganham força por traduzir imagens, emoções e movimentos, que alimentam a experiência bela daqueles que fazem ou assistem à cena. Logo, o aluno vive esta exploração diversificada das palavras, devido aos ricos momentos de interpretar cada personagem, que tem histórias e emoções diferentes. 
4) Valorizar o educando como criador: o texto no teatro pode ter sido escrito por um dramaturgo ou um grupo de artistas, mas também pode ser improvisado e criado no momento presente da encenação. Neste conjunto de possibilidades, o educando é mobilizado a agir como criador que vai escrever um texto teatral ou vai improvisar trazendo as palavras ao vivo. São estas experiências que colocam o aprendiz no exercício da produção textual, através do desafio de um personagem e de uma história a ser contada no enredo cênico.

Esta dimensão do imaginário se amplifica ainda mais no texto teatral infantil, pois a criança solicita uma exploração maior no mundo da imaginação livre e mutante. Uma história para criança é contada, no palco, com o foco maior na magia de transformar a cena em vários mundos diferentes. É como uma viagem metafórica por vidas e lugares em que é possível os personagens viverem, agirem e sentirem ao vivo diante dos olhos da criança que assiste. Diferente do cinema, a vida do palco está ali, no presente, e palpável para a criança. Mesmo quando o educando, apenas, lê o texto, os personagens ganham vida na entonação da voz e na emoção diante do que está acontecendo. É na força do teatro, enquanto "faz de conta", concretizado pelo instante do palco, que vivenciamos a liberdade de viajar na ficção ao vivo.

Conforme Lomardo (1994), a base do teatro é o jogo dramático, ou seja, qualquer ação em que se vivencie uma experiência imaginária, isto é, "um faz de conta". Aqui, compreendemos que o "faz de conta" consiste em fazer ou viver algo no teatro pelo prazer de jogar com o corpo, com a mente, com as palavras e com as emoções concretas no presente.

Segundo Guénoun (2004, p.147-148), "[...] há teatro por necessidade dos homens de jogar. [...] Só o teatro faz isto: só ele lança o poema para diante de nossos olhos e só ele lança e entrega a integridade de uma existência".

$\mathrm{Na}$ encenação teatral, portanto, os educandos têm a oportunidade de viver a experiência de construir a "existência" de um lugar fictício, a "existência" de um personagem e brincar com outra vida imaginária que é originada no texto teatral.

Revisitando os PCNs, observamos a importância do conhecimento artístico, em que:

Dramatizar não é somente uma realização de necessidade individual na interação simbólica com a realidade, proporcionando condições para um crescimento pessoal, mas uma atividade coletiva em que a expressão individual é acolhida. Ao participar de atividades teatrais, o indivíduo tem a oportunidade de se desenvolver 
dentro de um determinado grupo social de maneira responsável, legitimando seus direitos dentro desse contexto, estabelecendo relações entre o individual e o coletivo, aprendendo a ouvir, a acolher, e a ordenar opiniões, respeitando as diferentes manifestações, com a finalidade de organizar a expressão de um grupo (BRASIL, 1997, p. 83).

Assim, tais perspectivas para a didática teatral enfatizam o desenvolvimento do domínio do corpo do aluno, tornando-o mais expressivo, ao mesmo tempo em que ocorre um melhor desempenho na verbalização através das falas dos personagens; um desenvolvimento da capacidade para responder às situações emergentes com o exercício da criatividade; além de habilitá-lo a organizar melhor a noção de tempo e espaço com as narrativas cênicas.

\subsection{O desenvolvimento biopsicossocial do educando em cena}

Para Porcher (1982, p. 25) a educação artística possibilita "um desenvolvimento global da personalidade, através das formas mais diversificadas e complementares possíveis de atividades expressivas, criativas e sensibilizadoras". Entendemos as expressões artísticas nas suas diferentes manifestações e campos de conhecimento, tais como as artes visuais, a dança, o teatro ou a música.

O teatro fomenta o trabalho mais prático na sala de aula, onde o educando é estimulado a movimentar seu corpo, mudando, muitas vezes, o sentido fixo de se posicionar na sala de aula, geralmente, enfileirado. Nesta estratégia pedagógica dinâmica o aprendiz vivencia as atividades em círculo, expressando-se mais com o corpo pelo estímulo do fazer teatral. Dessa maneira, na dinamicidade, o aprender é acessado por outras vias, focalizando o corpo e as emoções, junto com as reflexões mentais.

As aulas na maior parte das disciplinas são direcionadas para uma aprendizagem que exagera na memorização e na racionalização, pressionando para que o aluno memorize textos, fórmulas e uma diversidade de conteúdos impregnados de teorias que excluem a prática. De acordo com Bosi (2004), a prática do gênero teatral nas aulas valoriza a presença criativa e dinâmica do educando em seu sentir, fazer e pensar, juntos no ato do aprender.

Por meio do teatro e de sua potencialidade estética, amplia-se a possibilidade de socializar a vida cotidiana com a turma, emergindo, a partir de determinado conteúdo de literatura, geografia, matemática, entre outras 
disciplinas, as próprias histórias de vida com todas as cargas emotivas e imaginárias. Neste sentido, verificamos que tal estratégia pedagógica é uma forma de construir aprendizagens, numa perspectiva de educação criativa para a vida. Duarte Jr. (2004, p. 185) explicita este valor da arte para o educando ao dizer que:

a educação estética refere-se primordialmente ao desenvolvimento dos sentidos de maneira mais fecunda e refinada, de forma que nos tornemos mais atentos e sensíveis ao acontecimentos em volta, tomando melhor consciência deles e, em decorrência, dotando-nos de maior oportunidade e capacidade para sobre eles refletirmos.

No exercício mais profundo e dinâmico da convivência, o teatro movimenta o educando em novos caminhos de percepção de si e do outro. Então, ocorre a abertura para uma convivência mais integrada, em que as diferenças são tornadas visíveis e conscientes para cada um. Assim, é possível o educando aprender, com os personagens de uma peça e suas peripécias, o respeito, a ética e o cuidado com si mesmo e com o outro, valorizando cada pessoa em sua história de vida e no contexto social. Esta aprendizagem passa pela experiência fictícia da cena, e podemos também chamá-la de virtual, pois se liga à dimensão do jogo não real. É um percurso para fazer emergir as potencialidades de cada educando através da virtualidade do "faz de conta" teatral, destacando-se que

todo homem se, sobretudo, toda criança trazem em si incríveis virtualidades de vida, de adaptação e ação, [...] cabe-nos redescobri-las, deixá-las germinar para basear nessas virtualidades dinâmicas todas as nossas intervenções educacionais (FREINET, 1998, p.141).

Dessa forma, o teatro explora diversos elementos virtuais, trazidos pelo onírico e pelo imaginário da literatura infantil, que se concretizam no palco. $A$ narrativa de uma história num texto escrito ganha vida na dimensão da cena. Quando trabalhamos o gênero teatral com a criança, devemos ficar atentos à riqueza do mundo simbólico que ela apresenta como virtual ou não palpável, mas que o teatro pode concretizar pelo corpo, pela voz, pelos figurinos e tantos outros elementos que jogam com a realidade fictícia.

A encenação de uma história, por exemplo, é a passagem de uma escrita no papel, com a riqueza de imagens e palavras, para uma escrita no palco que acrescenta o figurino, a sonoplastia, a iluminação, o cenário e os intérpretes. As palavras e as imagens do texto, que estavam no campo da imaginação do leitor, ganham toda a riqueza da cena concreta e palpável. Para o educando, isso é uma 
grande magia da arte, pois, na cena, é possível o aprendiz ficar diante de um rei, de uma princesa, de um soldado, de um animal teatralizado e que pode ser assistido ou interpretado por ele ao vivo.

Quando vemos o quanto a literatura infantil traz de história e personagens, percebemos o mundo a ser explorado pelo teatro. $O$ aluno se vê diante de uma diversidade de situações e personagens que um conto infantil apresenta, e como tudo isso pode ser reescrito na cena pelo corpo, pela emoção e pela imaginação. Assim, o uso do teatro na escola é algo que possibilita a oportunidade criativa para o educando fazer a releitura das histórias trazidas pela literatura infantil, com a magia cênica que explora a expressão oral e corporal, como processos lúdicos e criativos, contribuindo para o desenvolvimento biopsicossocial do aprendiz.

\subsection{O teatro enquanto estratégia pedagógica}

Primeiramente, é fundamental reafirmar que a arte tem a capacidade de transformar, esclarecer, fazer sonhar, imaginar, criar e recriar os comportamentos dos homens, tornando-os protagonistas de suas próprias histórias.

Nesta perspectiva, no trabalho com o gênero teatral desenvolvido em sala de aula, o professor pode aplicar diferentes práticas para o desenvolvimento da peça teatral. Aqui, ressaltamos três métodos, que estão ligados a nossa discussão sobre a literatura infantil, descritos a seguir.

1) Criação original: o educador pode guiar os educandos num processo de desenvolvimento de uma nova narrativa teatral livre. Ela deve ser criada a partir das ideias dos alunos ou de temas específicos ligados ao conteúdo do ano letivo. É um exercício de escrever um texto dramático, com as características de falas nos diálogos e uso de rubricas para descrever os ambientes e as emoções. Esta criação tem duas possibilidades de ser apresentada: uma montagem com o texto escrito e memorizado para ser visto pelo público ou a criação, apenas, de um roteiro que terá as falas dos personagens improvisadas na hora.

2) Adaptação: os educandos podem ter acesso a um conto ou qualquer tipo de texto narrativo ou não narrativo que pode ser adaptado para apresentar no palco. Esta adaptação passa pela escolha das histórias, das situações e dos personagens que farão parte de uma cena ou de um espetáculo. É um exercício, 
também, de criação, mas que parte de um elemento mais concreto e o foco é a adaptação, seguindo a coerência e a lógica do texto disparador.

3) Encenação: outra opção é a escolha de uma peça teatral já escrita para ser encenada. $O$ docente trabalhará os textos dramáticos, que estejam completamente prontos para serem utilizados numa montagem cênica, com os estudantes. É um processo que parte do estudo do texto, passando pela leitura dramática, pelos ensaios de memorização e marcação, até chegar à encenação final.

Tais estratégias são fundamentais na abertura de um leque de possibilidades, para o educador utilizar o teatro como caminho para colocar a teoria da disciplina numa prática criativa.

Aqui, apresentamos uma experiência com base no primeiro método, que é a criação original do texto dramático, enquanto estratégia pedagógica para ser aplicada, posteriormente, no Ensino Fundamental I.

Então, após as aulas teóricas e práticas, na disciplina de Literatura Infantil e Juvenil, ministrada pela Profa Dra Priscila Peixinho Fiorindo, no segundo semestre de 2014, na turma do Mestrado Profissional em Letras/PROFLETRAS/UNEB, um dos grupos ficou responsável por desenvolver uma história, no gênero teatro, a partir da seguinte orientação: criar uma narrativa que não existe.

Então, muitas dúvidas surgiram entre as alunas envolvidas, por exemplo, "Como faremos?" A resposta fornecida foi: "use a criatividade". Assim, o grupo composto por quatro alunas criou o enredo "De geração para geração..." , encenado em três atos.

O primeiro ato começa quando Rosa, a mãe das trigêmeas, recebe uma ligação das filhas que estão desesperadas, pois precisam montar uma peça teatral para apresentar no curso que fazem. Após o diálogo via telefone, a mãe pensa e pesquisa na internet sobre o assunto contos de fada, selecionando três personagens princesas, Cinderela, Branca de Neve e Tiana. Logo, como sugestão de atividade a mãe elabora um quadro mental, em que os referidos personagens casaram e tiveram filhas - Cindy, Bianca e Taiala, e imagina como seria uma conversa entre as filhas das princesas, nos dias de hoje, em pleno século XXI. A seguir, na Fig. 1, observamos os personagens criados por Rosa, em comum acordo com suas filhas: 


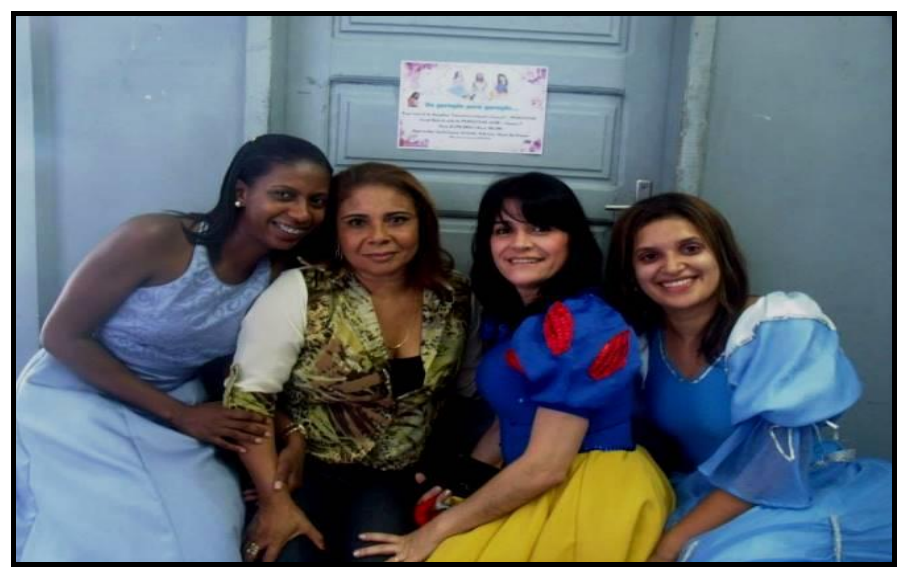

Fig. 1 - Taiala, Rosa, Bianca e Cindy.

No segundo ato, as princesinhas Cindy, Taiala e Bianca estão sentadas no meio da floresta conversando sobre seus sonhos e planos de princesas. Todas têm o mesmo discurso - encontrar o príncipe encantado. Então, na Fig. 2, visualizamos as filhas das princesas:

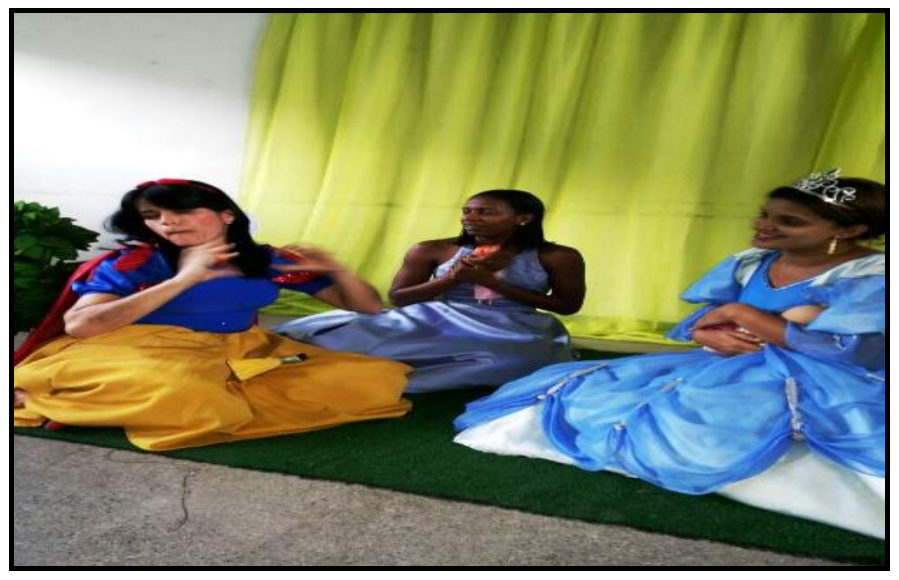

Fig. 2 - Bianca, Taiala e Cindy

A título de ilustração, transcrevemos, aqui, a fala de Bianca, que estava muito animada com o assunto:

E eu também. Pelo que se contam por aí parece que é muito bom estar apaixonada. $\mathrm{O}$ coração palpita quando vê a pessoa amada, a gente fica toda vermelhinha de emoção. Aiiii! quando falo em vermelho, só me dá vontade de comer maçã, mas eu não posso. Lá em casa a gente tem a síndrome da maçã. Se a gente comer, é capaz de morrer. Uma vez dei uma mordidinha em uma. Misericórdia!!! Dormi por dez dias. Aí agora eu resisto à tentação. Mas é duro! O vermelho me chama muito atenção. Ahh! Deixa essa história de maçã pra lá. Eu quero falar mesmo é de amor, de príncipe encantado. Será que eu vou sofrer como a minha mãe até encontrar meu amado. Espero que não. Minha mãe, coitada, sofreu muito até conseguir viver de vez com meu pai. Foi tanta perseguição, quase, quase que ela não conseguia escapar. Mas, graças a Deus, o amor venceu. Aquela 
madrasta desgraçada, por pouco, quase impediu a felicidade do meu pai com a minha mãe.

Conforme a fala de Bianca, observamos a referência ao conto de Branca de Neve, que, aqui, é representada por sua mãe. Paralelamente, constatamos o desejo da princesa de encontrar um príncipe encantado, pelos elementos presentes em seu discurso, como a cor vermelha e a maçã, que fazem parte do imaginário coletivo como símbolos do desejo e da paixão. Também verificamos o tom humorístico quando o personagem comenta sobre a mordidinha na maçã e a consequência - dez dias de sono contínuo.

No terceiro ato, 15 anos mais tarde, já na faculdade, as princesas, influenciadas pela maturidade do tempo, começam a refletir e comentar seus sonhos atuais, embora Taiala, ainda permaneça presa ao passado, acreditando que encontrará um príncipe. Nesta crença, ela não segue as orientações de sua mãe, como por exemplo, focar nos estudos, ter um bom emprego, ser independente. Logo, decide não assistir as últimas aulas na faculdade para ir à floresta em busca de um sapo, que se transformaria em príncipe após receber um beijo, como verificamos na Fig. 3:

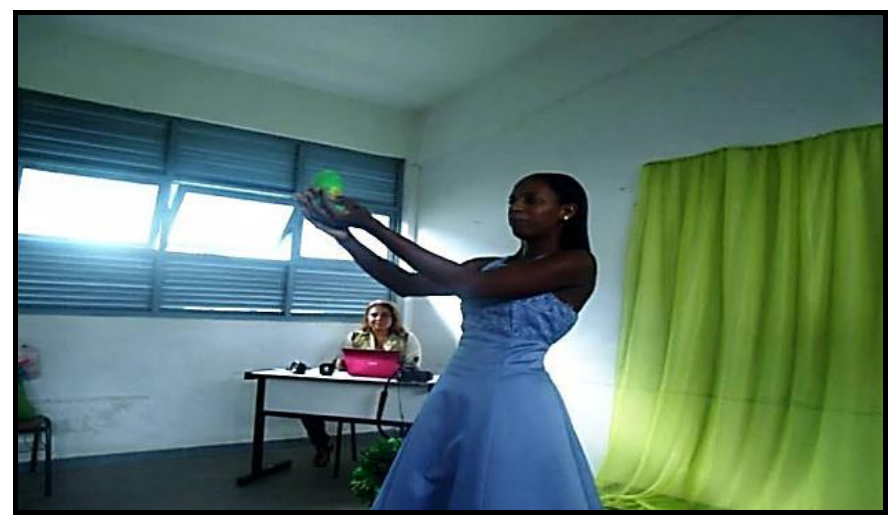

Fig. 3 - Taiala e o sapo

Então, Cindy e Bianca, inconformadas com a atitude de Taiala, decidem opinar sobre o que é mais adequado em nosso contexto atual, em que as mulheres devem ser independentes, seguras, mas não devem desistir de seus sonhos, como destacamos no discurso de Bianca, a seguir:

[...] Lá em casa, por exemplo, se o príncipe tivesse virado um sapo era bom. Mas não, sabe o que ele virou? Um homem chato, machista, que acha que a minha mãe tem obrigação de ficar só atrás dele, fazendo tudo que ele manda. Ainda por cima, só sabe peidar. Sinceramente, eu não sei como minha mãe tá aguentando ainda. Coitada. Tá que é uma tristeza só, vive deprimida chorando pelos cantos daquele 
castelo, que só serve pra dar trabalho, e hoje em dia não acha mais ninguém pra dar uma faxina. Eu que não quero esse destino pra mim.

De acordo com a fala de Bianca, observamos que ela traz elementos de seu mundo real, como, por exemplo, as referências a "homem machista", à "ausência de faxineiras" e à depressão, características presentes na atualidade. Tais elementos contribuem para a reflexão sobre comportamentos e atitudes a serem seguidos pelas mulheres nos dias de hoje.

Segundo Dewey (1978), o teatro enquanto experiência é visto como um espaço de escuta e troca, e esta atividade mostra que ele estimula a capacidade criativa, através de produções e apreciações estéticas, permitindo a autoexpressão, a reflexão crítica e a manifestação das emoções. Por esta via reflexiva, o teatro passa a ser um espaço de construção da cidadania, aqui entendida como atitude política, na qual o sujeito-social, conforme Heller (1972), coloca em prática a discussão sobre seus direitos e deveres.

Nesta perspectiva, os personagens envolvidos refletem no palco sobre seus comportamentos, enquanto seres sociais, "estimulando a formação de valores comprometidos com a solidariedade, a visão crítica do mundo, o respeito à vida e à dignidade humana" (MARFUZ, 2000, p. 38). Quando as estudantes, por meio dos personagens, trazem a temática ligada à mulher, elas estão usando a experiência teatral como um estratagema para desenvolver a consciência sobre a vida pessoal e social.

O teatrólogo Boal, ao dizer que "o teatro deve ser um ensaio para a ação na vida real" e que "o espetáculo é o início de uma transformação social necessária" (2005, p. 19), está atento ao potencial da vivência teatral, que é capaz de mudar a si mesmo, o personagem, e mudar o outro, o espectador, possibilitando novas oportunidades de autoconhecimento.

Prosseguindo, Bianca ainda ressalta sobre seus planos e projetos futuros:

Encantada vai ficar é a minha vida com tantos projetos que planejo. E esses sim, vão me fazer feliz de verdade. Eu sonho em ir morar lá no Brasil, na Bahia especificamente, ou melhor, em $S A J^{1}$. Dizem que lá é uma terra boa, só tem gente bacana. E ainda por cima tem um tal de PROFLETRAS, um curso de uma universidade de lá. Em um determinado momento, eles trabalham com a Literatura Infantil e Juvenil. Eu quero trabalhar nesse negócio pra alertar a mulherada desse problema de príncipe encantado. Vou jogar o caso no mato. Que nada! Viver um tempão iludida planejando encontrar seu príncipe pra depois descobrir que príncipe encantado não existe!!!!! Isso é uma malvadeza muito grande com a nossa classe.

\footnotetext{
${ }^{1}$ SAJ cidade de Santo Antônio de Jesus-BA
} 
Eu consegui me sair desse drama inteira! Mas quantas por aí que até o suicídio tentaram??? Deixa comigo!! Daqui a algum tempo ninguém nem vai saber que príncipe encantado tentou existir.

Por meio do discurso de Bianca, verificamos os projetos e planos futuros que as mulheres hoje almejam alcançar, como estudarem para, posteriormente, terem um bom emprego e não ficarem presas à cultura do passado, quando as funções da mulher, na sociedade, eram apenas casar e procriar. Ao afirmar que príncipe encantado não existe, o personagem mostra que hoje as mulheres podem escolher o que querem fazer, não necessariamente excluir o matrimônio, mas refletir sobre o melhor momento de se casar ou não. Mais uma vez, constatamos os elementos da realidade trazidos para o mundo lúdico da encenação.

Nesta perspectiva, a arte através do entretenimento possibilita a criticidade no público. Ferraz e Fussari (1995, p.15) afirmam que "a arte se constitui de modos específicos de manifestação da atividade criativa dos seres humanos ao interagirem com o mundo em que vivem, ao se conhecerem e ao conhecê-lo". Com esta definição, observamos que a arte tem um efeito direto no contexto cotidiano do educando e com elementos dinâmicos de mobilização e interação.

Ostrower (1990, p.7) diz que "a fonte da criatividade artística, assim como de qualquer experiência criativa, é o próprio viver". Nesta vertente, a arte pode trabalhar de forma direta com os problemas e necessidades do dia a dia da pessoa, colaborando para a crítica social e para uma visão mais consciente das relações interpessoais.

Com a "arte os indivíduos ampliam o conhecimento de si próprios através da descoberta dos padrões e da natureza de seu sentir" no dizer de Duarte Jr. (2003, p. 66). Esta percepção possibilita uma tomada de consciência determinante do indivíduo no seu contexto social, evidenciando que a arte é um elemento fundamental na consciência global do indivíduo, na vivência familiar, na comunidade e na relação consigo mesmo.

Assim, o teatro apresentado pelas mestrandas do PROFLETRAS/UNEB mostrou, durante toda encenação, a relação das estudantes com a vida pessoal e o contexto profissional de cada uma.

Ao finalizar a peça, houve um baile com a participação dos convidados, a plateia, e todos viveram felizes como uma imitação cênica dos contos clássicos. Esta ideia de felicidade é o que está por traz do sonho das estudantes e do olhar 
de esperança para o cotidiano. É o teatro possibilitando a realização concreta dos sonhos no palco. Posteriormente, as alunas/atrizes se despediram e agradeceram a presença do público, na Figura 4:

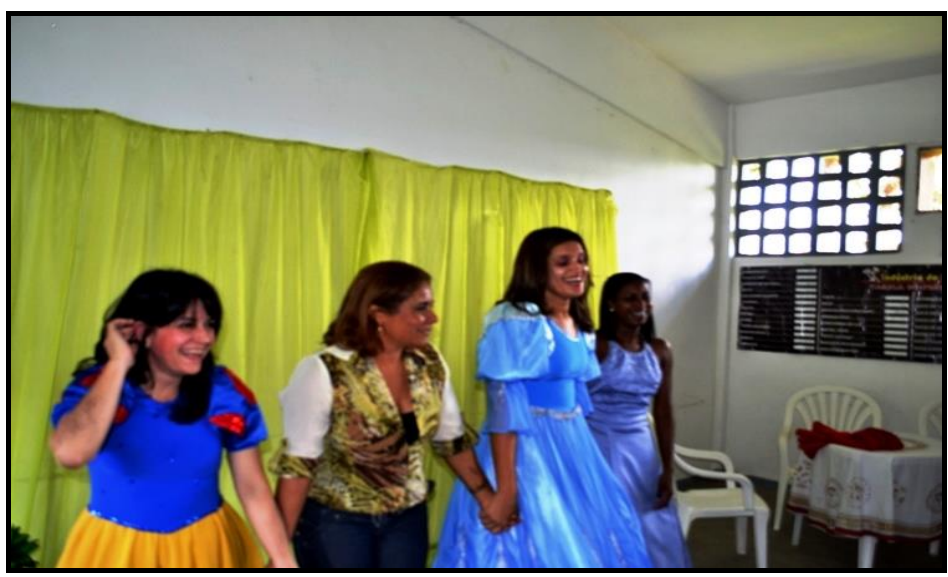

Fig. 4 - Bianca, Rosa, Cindy e Taiala

\section{Considerações finais}

A partir do exposto, observamos que quando a teoria é aliada à prática, é possível ensinar, encantar e partilhar os conhecimentos de forma mais interessante. A experiência vivida pelas alunas mostrou que a literatura, apresentada no gênero teatro, contribui para a reflexão acerca de acontecimentos cotidianos a partir da ludicidade.

Nesta perspectiva, na experiência cênica do espetáculo "De geração para geração", ressaltamos três resultados de aprendizagens pedagógicas, descritos a seguir.

Aprender a criar com originalidade: o exercício de criar de forma diferenciada e única uma história levou as mestrandas a descobrirem caminhos inusitados para o enredo, que mesclou elementos da realidade cotidiana com o imaginário fantástico dos contos infantis. São as experiências que levam os educandos a terem um desafio criativo em suas mãos, partindo de um estímulo para uma obra teatral, em que os conhecimentos são apreendidos no decorrer da prática e da descoberta de cada novo elemento.

Aprender a criar com a fluência da oralidade: destacamos aqui as falas, que as estudantes apresentaram durante o espetáculo, para afirmar o valor da oralidade enquanto um dos elementos pedagógicos que une o teatro à literatura. Cada fala de um personagem tem sua estrutura e pode ser usada como material 
didático em sala de aula. Foi a partir destes personagens e de suas réplicas que as alunas puderam viver a riqueza da fluência de ideias e emoções através da expressão oral.

Aprender a criar com criticidade: na análise que fizemos da experiência teatral, mostramos as reflexões culturais, sociais e políticas apontadas nas falas das alunas. A utilização do teatro como estratégia pedagógica, pode levar os educandos a estabelecerem opiniões a partir de cada personagem e situação cênica vivida. É a cena criada no palco que leva o educando a olhar a cena na vida, com observação dos detalhes nas relações humanas, na compreensão das diferenças, que fazem parte de uma sociedade que precisa ser transformada.

Dessa forma, vimos que a partir de uma experiência teatral com a literatura infantil foi possível mostrar diferentes estratégias pedagógicas que são úteis para os professores no Ensino Fundamental I, pois nossas crianças e jovens solicitam novos caminhos metodológicos que animem e dinamizem o aprendizado, mostrando que a escola é um lugar do aprender com prazer, por meio da criatividade e da ludicidade que encantam e transformam.

\section{Referências bibliográficas}

ALCOFORADO, D. F. X. Literatura oral e popular. Boitatá - Revista do GT de Literatura Oral e Popular da ANPOLL, no especial ago-dez, 2008: 10-116.

BOAL, A. Teatro do oprimido e outras poéticas políticas. $7^{a}$ ed. Rio de Janeiro: Civilização Brasileira, 2005.

BOSI, A. Reflexões sobre a arte. $7^{\text {ạ }}$ ed. São Paulo: Ática, 2004.

BRASIL. Parâmetros curriculares nacionais. Artes. Brasília: Ministério da Educação, 1997.

Parâmetros curriculares nacionais. Língua Portuguesa. Brasília: Ministério da Educação, 1998.

COELHO, N. N. O ensino da literatura. São Paulo: FTD, 1966.

COSTA, S. R. Dicionário de gêneros textuais. Belo Horizonte: Autêntica, 2008.

DEWEY, J. Vida e educação. Tradução Anísio Teixeira. 10 ed. São Paulo: Melhoramentos, 1978.

DUARTE JR., J. F. O que é beleza. 3ª ed. São Paulo: Brasiliense, 2003. 
O sentido dos sentidos: a educação (do) sensível. $3^{\text {a }}$ ed. Curitiba: Criar Edições, 2004.

ESSLIN, M. Uma anatomia do drama. Tradução Bárbara Heliodora. São Paulo: Zahar Editores, 1978.

FERRAZ, M. H. C. de T. e FUSSARI, M. F. de R. Metodologia do ensino da arte. São Paulo, Ed. Cortez, 1995.

FREINET, C. A educação pelo trabalho. São Paulo: Martins Fontes, 1998.

GUÉNOUN, D. O teatro é necessário? Tradução Fátima Saadi. São Paulo: Perspectiva, 2004.

HELLER, A. O quotidiano e a história. Rio de Janeiro: Paz e Terra, 1972.

LOMARDO, F. Teatro infantil. São Paulo: Brasiliense, 1994.

MARFUZ, L. Tecnologia educacional com o teatro: fundamentação teórica, princípios e reflexões. v. 1. Salvador: Liceu de Artes e Ofícios da Bahia, 2000.

OSTROWER, F. Criatividade e processos de criação. Petrópolis: Vozes, 1990.

PORCHER, L. Educação artística: luxo ou necessidade. São Paulo: Summus, 1982.

SARMENTO, L.L e TUFANO, D. Português: literatura, gramática, produção de texto. São Paulo: Moderna, 2010. 
Artigo recebido em: 13 de dezembro de 2014

Artigo aprovado em: 25 de março de 2015

Sobre os autores:

Priscila Peixinho Fiorindo é Professora Adjunta da Universidade do Estado da Bahia - UNEB. Coordenadora do Grupo de Pesquisa Psicolinguística: perspectivas interdisciplinares/UNEB.

Ney Wendell possui pós-doutorado em Sociologia pela Université du Québec à Montréal-UQAM, doutor e mestre em Artes Cênicas pela UFBA, licenciado em Teatro pela UFBA, arte-educador, diretor teatral, escritor e gestor de projetos sociais e educacionais. 